\title{
Shanghai and New York: Mid-Century Urban Avant-Gardes
}

\author{
Rosemary Wakeman \\ History Department \& Urban Studies Program, Fordham University, New York, United States \\ Email: rwakeman@fordham.edu
}

\begin{abstract}
This article examines the cultural and architectural exchanges between Shanghai and New York in the mid- $20^{\text {th }}$ century and their iconic roles as avant-garde global capitals. It considers the cultural and architectural free-thinkers and the groundbreaking movements they led, as well as their influence on the character and identity of both cities. Art Deco was the emblematic symbol of these modern forces. The article analyses the new technologies and theatrical perspective, the performative and spectacular qualities of Art Deco as the signature styles and cultural heritage of both cities.
\end{abstract}

KEYWORDS Art Deco, New York, avant-garde, Radio City Music Hall, Park Hotel, lighting design, technology, Cathay Cinema, cityscape, film

Received May 12, 2019; accepted August 15, 2019.

In the 1920s and 1930s, New York and Shanghai were bustling cosmopolitan metropolises, melting pots of nationalities and by extension architectural styles from around the world. New York was already a metropolis of some 7 million people and just behind London as the largest city in the world. With 3.2 million inhabitants in 1932, Shanghai was the fifth largest city in the world. Its population increased to 5 million by the end of the 1930s. Both cities were teaming ports and places of encounter with a flux-and-flow of peoples moving across borders and frontiers. They were shaped by exchanges and the mingling of publics, ideas, trade. This circulation of peoples and cultures, the collision of all these ideas and ways of seeing was a boiling cauldron of creativity. They made New York and Shanghai into global pivots for the production and consumption of urban modernity. The modern temperament, the famous New York and Shanghai 'styles', was defined by skyscrapers, department stores, and their glitzy ballrooms and jazz dance clubs. Their built heritage comprised manifold cultures. Both cities were the sites of competing architectural styles- neoclassical and pompous Beaux-Arts buildings sat alongside Art Deco towers that exemplified the new age. The aesthetic tensions that existed in New York and Shanghai created mesmerising cityscapes that was already legendary in the 1930s.
Much has already been written about New York and Shanghai in the 1930s. The scholarship on 'Art Deco New York' and 'Art Deco Shanghai' is multitudinous. This article focuses more narrowly on specific facets of this heritage. It broadens out the imaginary of built heritage to include the composite of cosmopolitan influences that shaped the urban fabric, and that made these cities into global crossroads. While the influence of New York and the American architectural idiom on Shanghai is taken fully into account, the article argues that similar avant-garde influences inspired architects in both cities and predisposed the way their built environments were produced. It takes a closer look at architecture as urban theatre and redefines architectural space to include what are often considered ephemeral or inconsequential elements, and yet were decisive in making architecture into avant-garde production. Specifically, new building technologies and theatre design were both at the nexus of perceptions about modernism and urban form. Technology was the guiding leitmotif of the $20^{\text {th }}$ century. Technology along with architecture in the service of mass culture and consumption, popular entertainment and urban spectacle opens a rich perspective on built heritage. It ties it to the myriad transformations that made New York and Shanghai into modern urban icons. 


\section{Art Deco as Future City}

It was the Art Deco skyscrapers that crowned their skylines in the 1920s and 1930s that made New York and Shanghai into unabashed icons of the future. Rockefeller Center, the Chrysler Building, and the Empire State Building in New York were glorious signatures of urban modernism as were Shanghai's Park Hotel, the Sassoon House, and Broadway Mansions. Of course, not everyone was convinced that the skyscraper was the future. Venerable American urban theorist Lewis Mumford called New York's skyscrapers 'a blind alley and an insupportable luxury' (Mumford 1933). But for the majority gazing up at the soaring towers, Art Deco was the vision of a futuristic city. It formed part of a cosmopolitan imagination emanating from the West. Architects consciously abandoned the historical forms that dominated architecture up to the 1920 s as stogy and unsuitable to the modern age. Instead, they found inspiration from a wild variety of sources in what amounted to a global intermixing of styles. Art Deco exuded optimism and aesthetic exuberance. It was a spectacular statement of 'newness', of a future filled with possibilities. It was an immediate international sensation, infusing cities across the globe with a scintillating verve, an architectural jazz that matched the modern age. Although profoundly eclectic, it was the technology that pervaded modern life that most infused the new Art Deco aesthetic. Architects and designers embraced airships and cruise ships, the whirring cogs and wheels of the factory. They rendered the machine aesthetic in linear and geometric forms and cubist volumes, in sumptuous metals, zigzag and streamlined configurations that evoked the energy and power of technology. They explored the interplay of planes, the juxtaposition of patterns, colours and textures. In this regard, the impact of the 1925 Paris Exposition des Arts Décoratifs et Industriels Modernes on New York as well as on Shanghai was profound and rapid. The Exposition graced the Seine River in the west of Paris from April to October that year with an official attendance of over 15 million people. The exposition was itself a place of fantasy and wonder. Under the banner of 'Art Deco', the Exposition challenged participants with an avant-garde credo: 'Works admitted to the Exposition must show new inspiration and real originality.'

It was this experimental aesthetic temperament that made Art Deco so adaptable across cultures. Rather than simply emulate Paris, when it was transplanted internationally, the design took on different meanings and fashioned distinct New York and Shanghai 'styles'. In New York, Art Deco was the signature of a triumphant capitalism, while in Shanghai, it was a visible sign of the colonial presence and a mesmerising newness invented in the West. Alluding to the lesser role that Shanghai often played in relation to the great western capitals, the publisher of The China Journal argued that Shanghai 'must show that it is one of the "Great Three" along with London and New York ... Shanghai is the London, New York and Paris of the East, all rolled into one' (Sowerby 1928, 114). Shanghai was becoming 'an apartment city just as are New York and London'. At the same time, the cosmopolitan qualities of Art Deco were directly connected to Eurocentrism. A plea for Chinese expertise in modern architecture asserted that "We want variety in the "brave new world". We most emphatically do not want an exact reproduction of Europe or America in Asia.' (North China Herald 1929, 1934) Yet in this dialogue between east and west, the resemblances between the cities were as provocative as their differences. In both cities, Art Deco symbolised money and power and took on a hegemonic caste (Lee 2001, 9295). It is easy to interpret this heritage as a capitalist logic exulting in the flashy facades. It was the rich and famous who inhabited the luxurious Art Deco skyscrapers rising on the skylines, and their glamorous lives became the stuff of Hollywood films shown in the cinemas of Shanghai and New York. The Bund and Fifth Avenue were the frontiers of global capitalism.

If architecture exuded wealth and privilege, it was also a product of the crossroads positions of both cities, a kind of migratory or melting pot modernism that scaled territorial frontiers and wandered through urban cultures, imbibing local design practices, picking up fragments and adapting to local aesthetics. British sociologist Gerard Delanty argues that there are moments of world openness in which the encounter between the local and the global shaped cultural modes of mediation (Delanty 2006, 27). The avant-garde production of the 1920s and 1930s was indeed such a moment. In both cities, the genealogical roots that made up this cultural mélange were many, and the meaning of this modernist heritage goes beyond the hypnotic decorative spell that Art Deco caste. It was a form of global cultural knowledge situated in the local (Windover 2009, 24). The geometric forms and motifs of East Asian decorative art added to the mix as did Futurism and Constructivism. Central European avant-garde design was a significant ingredient to this stew of global influences, as were avant-garde theories of democratic theatre and mass society, along with the technological wizardry of engineering and communication media, and dreams of cities made up of spiny-needle skyscrapers. In the hands 
Figure 1 Walter Gropius (18831969), 1927. Berlin: Total Theatre: Plan deep stage in position (Source: ARTSTOR).

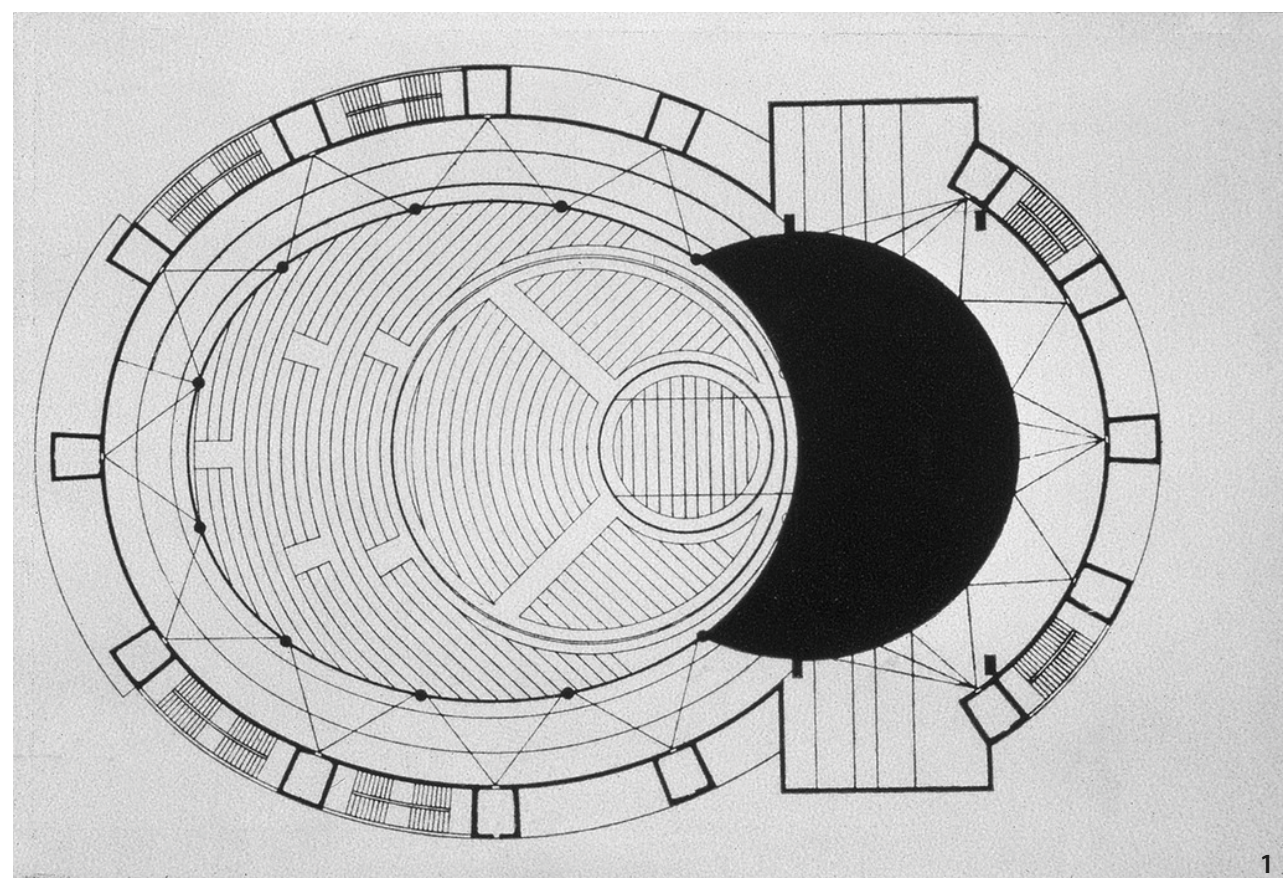

of the avant-garde, these appealed to the emotions and the imagination. They made up a broad modernist heritage in which the 'irrational fantasies', as Rem Koolhaas called them, about the future city came to full light (Koolhaas 1997, 173).

\section{Art Deco as Aesthetic Mélange}

A host of official American delegates from organisations such as the American Institute of Architects wandered through the 1925 Paris Exposition, stunned at the radically new design in architecture, furniture, textiles and graphics. In February the next year, New York's Metropoli$\tan$ Museum of Art welcomed visitors to their miniature version of the Paris Exposition with 'A Selected Collection of Objects'. New York's most prominent architects of midcentury modernism, individuals such as Harvey Wiley Corbett, Raymond Hood, Wallace Harrison, and Edmund Durell Stone, had all been trained in Europe, primarily at the Ecole des Beaux Arts, and were immediately inspired by the designs they viewed at the 1925 Exposition. These were the designers behind Rockefeller Center and Radio City Music Hall, perhaps the penultimate examples of New York's avant-garde Art Deco architecture. They set off on a European grand tour, searching out avant-garde theatre designs and meeting up with German architects such as Expressionist Erich Mendelsohn to see his streamlined Universum Cinema and indulging in discussions with Peter Behrens and Walter Gropius. Gropius had applied his concept of 'total theatre' to the architecture and design of the playhouse itself (Figure 1). As part of the broad social theory shared by these cosmopolitan elites, the modern theatre was imagined as a mass democratic medium (Gropius and Schlemmer, 1924). The focus was on dramatic technique and technics. Revolutionary uses of space, form, colour, sound, motion would dissolve into the shifting, illusionary arena of the imagination. The New York architects eagerly adapted these European expressionist and modernist configurations to the city's building boom. The emotional and decorative effects of colour and pattern, and illumination were in full view in Rockefeller Center (which received official landmark status in 1978).

Although the European avant-garde was a touchstone, New York's version of Art Deco was more commercial, more geared to the entertainment industry and certainly more flamboyant. Donald Deskey was characteristic of mid-century modernists such as Wallace Harrison and Raymond Hood, as well as Edward Durell Stone. Schooled at the Ecole des Beaux Arts, Deskey made a second trip to Paris in 1925 to attend the Exposition des Arts Décoratifs. The spectacle of chrome and steel, the plastic, the straight lines and sharp edges were a revelation for him. He continued his sojourn in Europe with a pilgrimage to the Bauhaus in Dessau. On returning to New York, he was hired to decorate the windows of department stores along New York's famed Fifth Avenue. Like many cutting-edge American designers of this period, he worked in advertising and sallied back-and-forth between theatre design, marketing, and industrial design. The avant-garde decorative drama he concocted for department store displays 


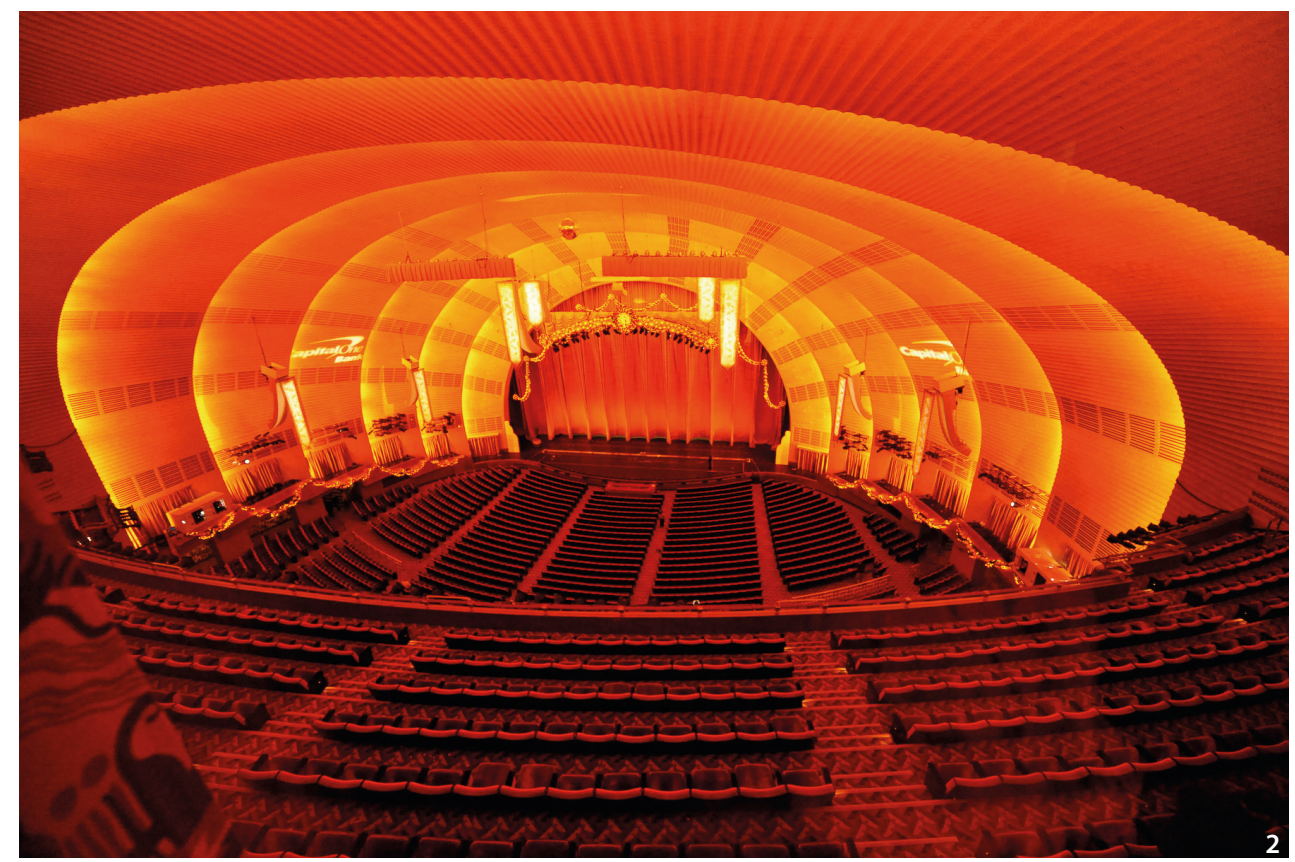

Figure 2 Radio City Music Hall, Rockefeller Center, interior, auditorium with view toward Great Stage. Edward Durell Stone, principal architect; Donald Deskey, interior designer (Source: Wikipedia Commons).

were an immediate sensation and spurred Deskey to join with Hood, Harrison, and Viennese designer Paul Frankl in promoting modern design and architecture. Deskey introduced mass-produced tubular metal furniture based on designs by Marcel Breuer and Ludwig Mies van der Rohe he had seen at the Bauhaus. But European modernism was not the only source of inspiration for American designers. They turned to the burgeoning American consumer industries as mechanisms for a revolution in everyday life. It was evident in Deskey's 20-year association with the Procter \& Gamble Company during which he designed dozens of domestic household products.

Deskey's design of Radio City Music Hall promised avant-garde architecture of the 1930s as visual theatre. Deskey worked with theatrical set designer Edmond Jones to fashion the interior of Radio City Music Hall as a bold spectacle of cubist forms, rich materials, glowing metal surfaces, with a sumptuous Art Deco golden crown enveloping the stage (Okrent 2003, 222-230). Marble and gold foil mixed with aluminium and cork in a blaze of decorative light fixtures and enormous murals (Figure 2). The North China Herald pronounced it 'the largest and best theatre in the world' (29 March 1939). The theatre revealed the lighting effects that were essential to creating mid-century architecture and design as theatre. In his Event Cities, Bernard Tschumi argued that architecture is both a performance and an event. It is a mise-en-scene where vectors, voids, solids, envelopes and flow negotiate the delicate relationship between space, movement and action (Tschumi 1994, 13). Art Deco was a formula for carrying out this vision and reconceptualising spatial context and texture. Colour and artificial lighting were an integral component of this theatrical built environment. Journalists remarked on Radio City Music Hall's scale, its showmanship, with its interior 'flooded with enough light, mostly coloured light, to illuminate the city of Minneapolis. Lighting was treated by modernists as pure colour and form. The illuminating experts 'can weave together effects like aurora borealis, sunrise at sea, shooting-star showers, burning cities .... The architects used tricks of perspective to shorten distances with the walls and ceilings curving into the stage (New Yorker Magazine 1932, 48-50). Like Art Deco itself, illumination was exuberantly decorative and ostentatiously ornamental. It was the moderne style that dazzled and thrilled the crowds, and augured the urban future.

Like their New York counterparts, Chinese architects and artists such as Liu Jipiao and Lin Fengmian made the pilgrimage to Paris, enrolled in the Ecole des Beaux Arts and toured the 1925 Paris Exposition. Liu Jipiao designed the interior of the Exposition's Chinese Pavilion in a flamboyant moderne style. Art Deco arrived in Shanghai through a pair of young French architects, Alexandre Leonard and Paul Veysseyre. They began work on the Cercle Sportif Français, a lavish country club in the western part of the French Concession. Opened in 1926, the French Club, as expatriates called it, presented a conservative Beaux-Arts exterior fronting its style moderne interior in imitation of that showcased at the 1925 Paris Exposition. Leonard and Veysseyre went on to complete over a 
Figure 3a Park Hotel, Laszlo Hudec architect, 1934 (Source: Virtual Shanghai.net).

Figure 3b American Radiator Building, Raymond Hood architect (Source: Irma and Paul Milstein Division of United States History, The New York Public Library. Accessed June 27, 2019).
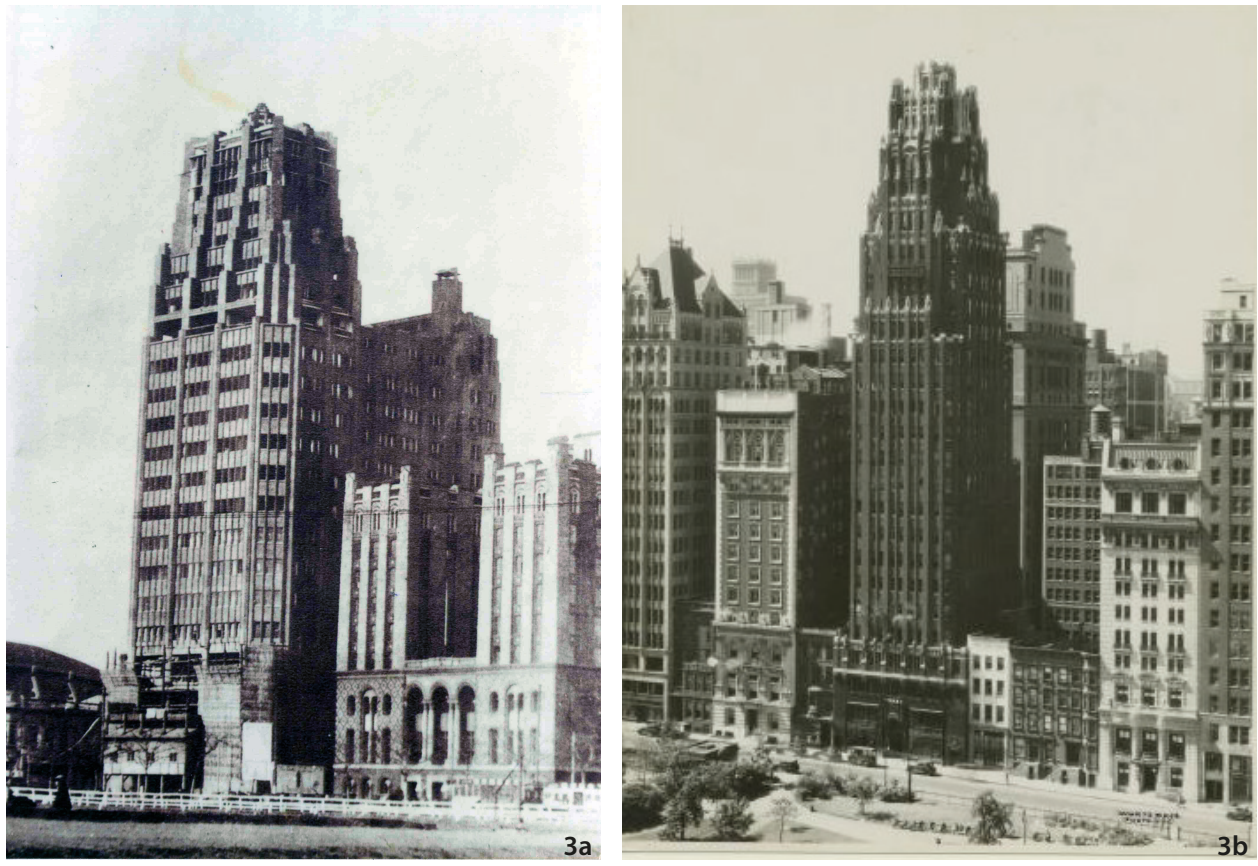

hundred commissions, most of them in the Art Deco style. But they were not the only champions of the eclectic modernism of Shanghai. There were also Hungarian-Slovak László Hudec, Englishman George 'Tug' Wilson, Russian Alexander Yaron, Spaniard Abelardo Lafuente (see the article by Álvaro Leonardo Pérez in this issue), and an expanding roster of foreign-trained Chinese architects such as Robert Fan and Dong Dayou. Following the pattern seen elsewhere around the world, the city's architects combined a potpourri of architectural traditions with the more 'universalist' imported elements of Art Deco. László Hudec represented this fusion of patterns. Like many of the refugees fleeing the former Austro-Hungarian Empire, Hudec was early on influenced by the atmospheric qualities of German Expressionism, especially that of Erich Mendelsohn. By dint of refugee status, Hudec along with other expatriate architects became 'citizens of the world'. He maintained contact with the European architectural avantgarde throughout his career. Hudec initially worked for the American architectural firm of Roland Curry in Shanghai. A trip to America to study New York's skyscrapers profoundly shaped his ideas, especially the verticality of buildings by architect Raymond Hood (Figures 3a, Figure 3b). Hudec's landmark Park Hotel in Shanghai was based on his sketches of Hood's American Radiator Building (dedicated to the new heating technology) at New York's Bryant Park (Poncellini 2010). The Park Hotel was Shanghai's first skyscraper and long the city's tallest building.

In his book New Dimensions (1928), New York-based Viennese designer Paul Frankl defined skyscrapers as the monument of American business and enterprise, and an American visitor to Shanghai remarked that the skyscrapers along the Bund were 'monuments to the prosperity of the owners and to the possibilities of Eastern trade' (Frankl 1928, 61; New York Times, 25 February 1923). They were the world of big business and international commerce. The advent of the New York skyscraper as ideal of the future meant an Americanisation of architectural production and a rising demand for American materials and architectural know-how. Surveying the dizzying height of New York's skyscrapers (Figure 4), a Shanghai journalist remarked 'There literally seems to be no limit ... The modern skyscraper is gradually producing a new species of human beings.' Architect George Wilson reported in The China Journal on how 'the pleasing effect of the modern American skyscraper' in New York came about (Wilson 1932, 238). The American Institute of Architecture, the United States government, as well as American educational and philanthropic organisations championed the growing presence of American architects and builders in Shanghai. Foreign businesses confronted an increasingly powerful Chinese nationalist movement that targeted the treaty system and foreign privilege. Yet even in the chaotic Republican era, city-building functioned around avantgarde international networks. American engineering firms were involved in the construction of new electric power plants and substations in Shanghai as well as the expansion of telephone service. Architectural schools such as the University of Pennsylvania and Pratt Institute in New York were opening their doors to Chinese students such as 


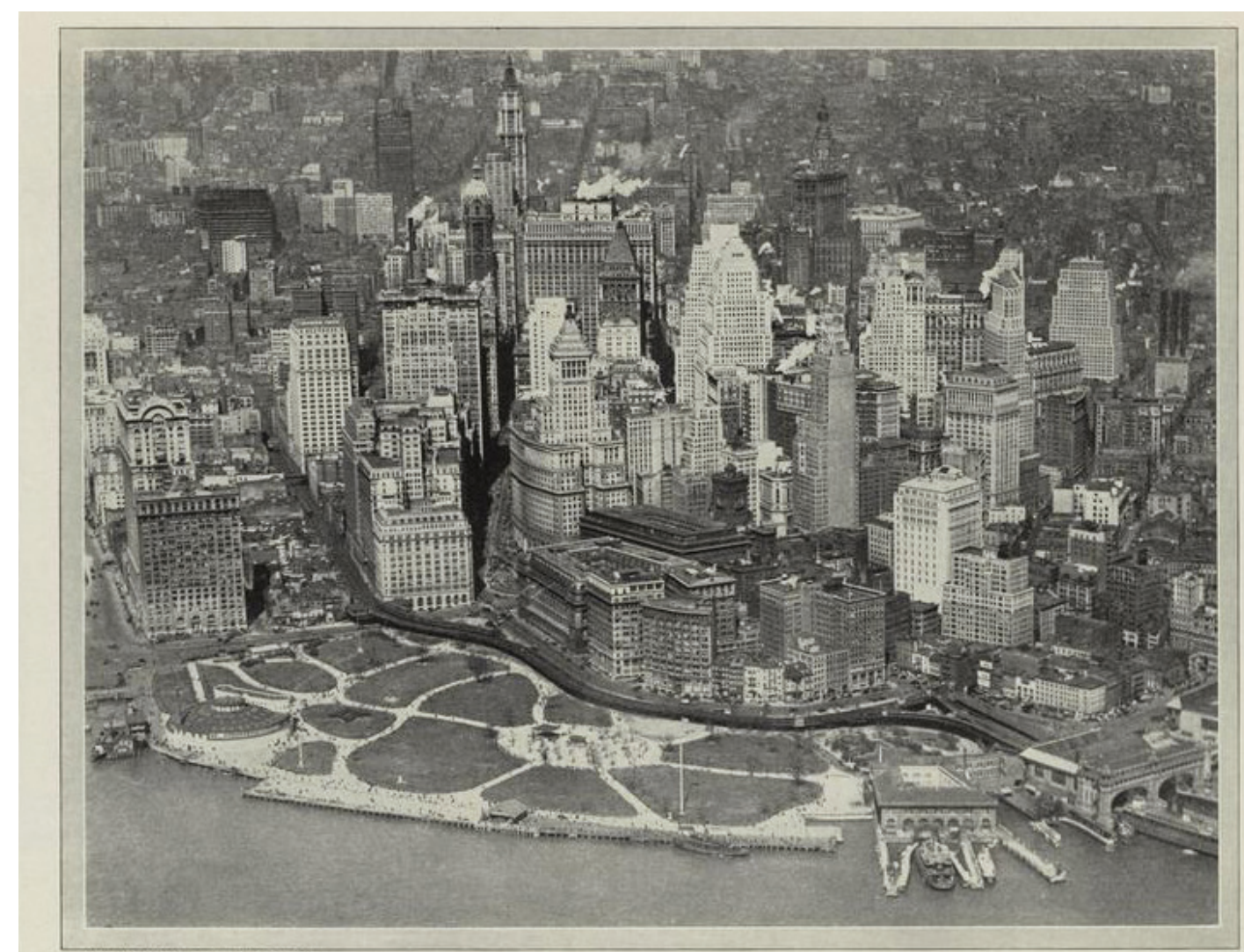

SKYSCRAPERS OF NEW YORK CITY

Aerial view of Battery Park and the skyserapers of lower Mankattan, looking norttwarts

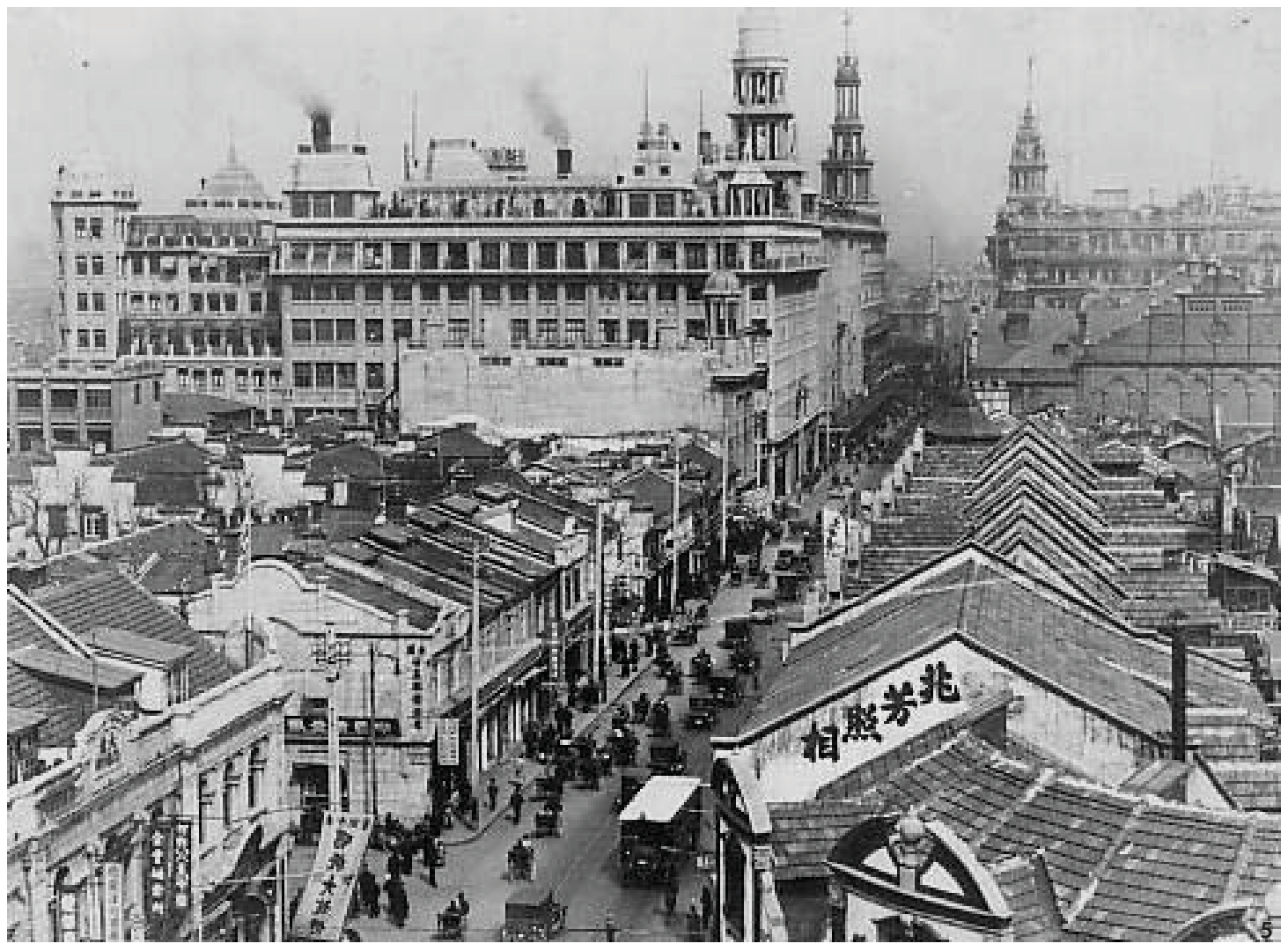

Figure 4 Skyscrapers of New York City: aerial view of Battery Park and the skyscrapers of lower Manhattan, looking northwards, 1929 (Source: New York Public Library Digital Collections. Accessed June 26, 2019).

Figure 5 Nanjing Road (Source: Japanese book Nostalgia for Shanghai published by Kokusho-kankoukai). 


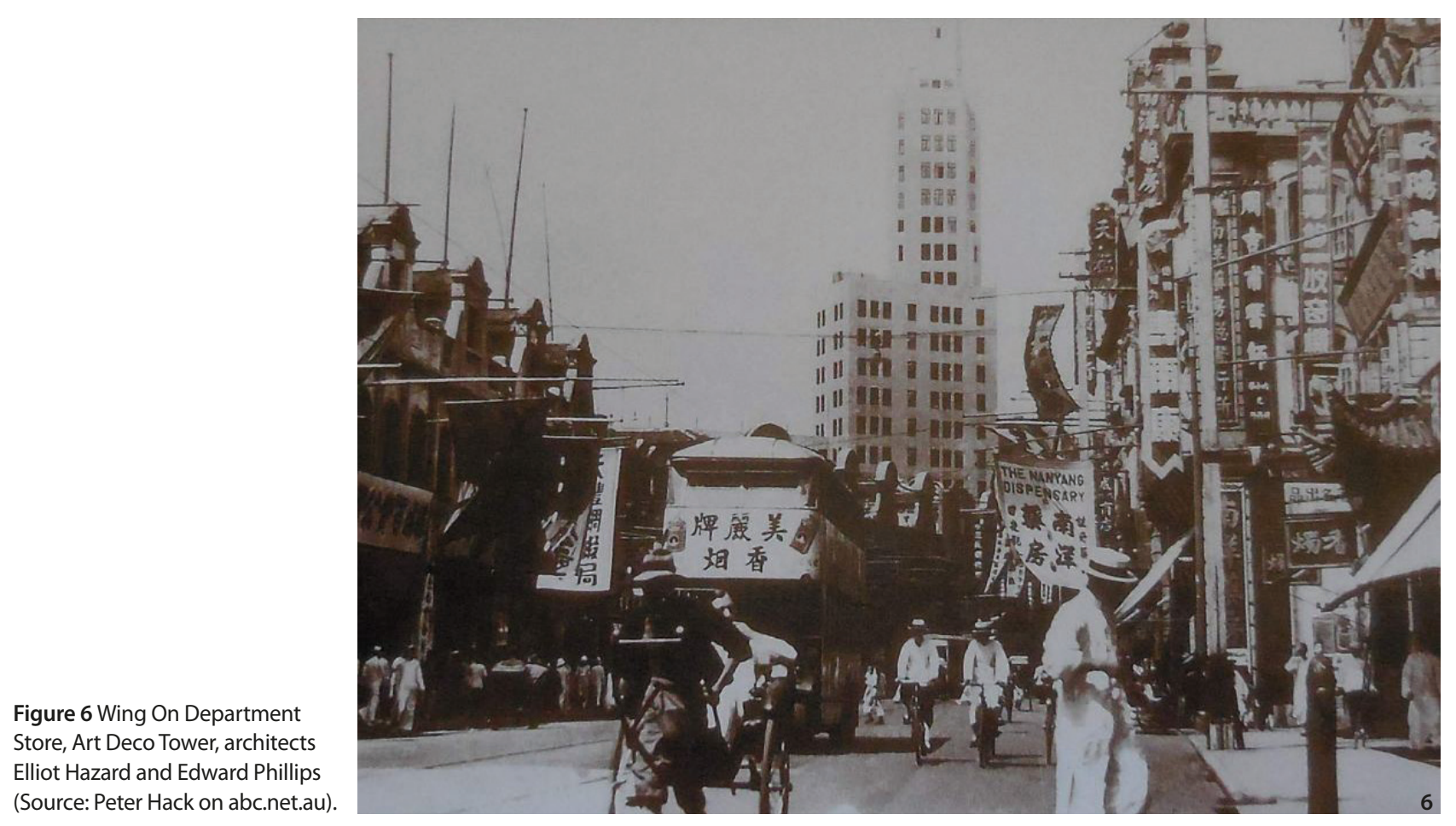

Liang Sicheng, Yang Tingbao, Chen Zhi, Zhao Shen, and Lin Huiyin. They were instrumental in bringing American practices and standards to China and merging them with local aesthetic traditions and heritage. With architectural offices in Shanghai, the New York firm of Henry K. Murphy employed Art Deco trendsetters Elliot Hazzard and Poy Gum Lee as well as a number of Chinese architects. Cathay Mansions was likened to '... one of the more magnificent apartment houses in New York City ...' (North China Daily News, 14 November 1932 and North China Herald, 19 May 1932). The richness of display on Nanjing and Bubbling Well roads made them into Shanghai's 'Great White Way' in imitation of Broadway (Figure 5).

\section{Art Deco as Technics}

These references to an American-style Deco design evidenced the increasingly influential role New York played in the Shanghai imagination. New York architects Elliot Hazard and Edward Phillips designed the 26-storey Art Deco tower extension of the Wing On Department Store (Figure 6). It was a mark of the intimacy between Art Deco design, advertising and commercialism. The tower rose over Nanjing Road across from the Sincere Department Store and fashioned the intersection into what was dubbed Shanghai's 'Times Square' (Denison 2017, 277). Hazzard also designed the Shanghai Power Company Building on Nanjing Road. The reinforced concrete
Art Deco building mirrored construction in New York, where caste aluminium spandrels were also being used, for example, in Rockefeller Center. Concrete, steel framing and aluminium were then adapted to the structure of Broadway Mansions in Shanghai by Scottish architect Bright Fraser. Shanghai's Art Deco buildings introduced the automatically-controlled Otis elevators and escalators, the air-conditioning and heating, the automatic sprinklers and fire alarm systems, that made skyscrapers practical and also made them technological marvels. Even the reinforced pilings that made raising the towers possible in the Shanghai mud were based on new engineering technologies. Architectural modernism was tightly bound with this machine culture. The majority of these engineering and construction feats were done by American and German companies although Chinese firms were also subcontracted for building construction.

The Art Deco buildings rising along Nanjing Road and on the Bund were conjured from this technological wizardry. They emerged alongside the development of photography and cinematography, radiography, telephony, electricity, and engineering. 'Modern genies who, on a flat mud bank, rear cement and concrete palaces to the sky ...' reported the North China Daily News (14 November 1932). Technology made possible the functionality, the movement and circulation that were the unquestionable basis of modernist architecture as well as modern life. Technology was not merely contextual, but instead 


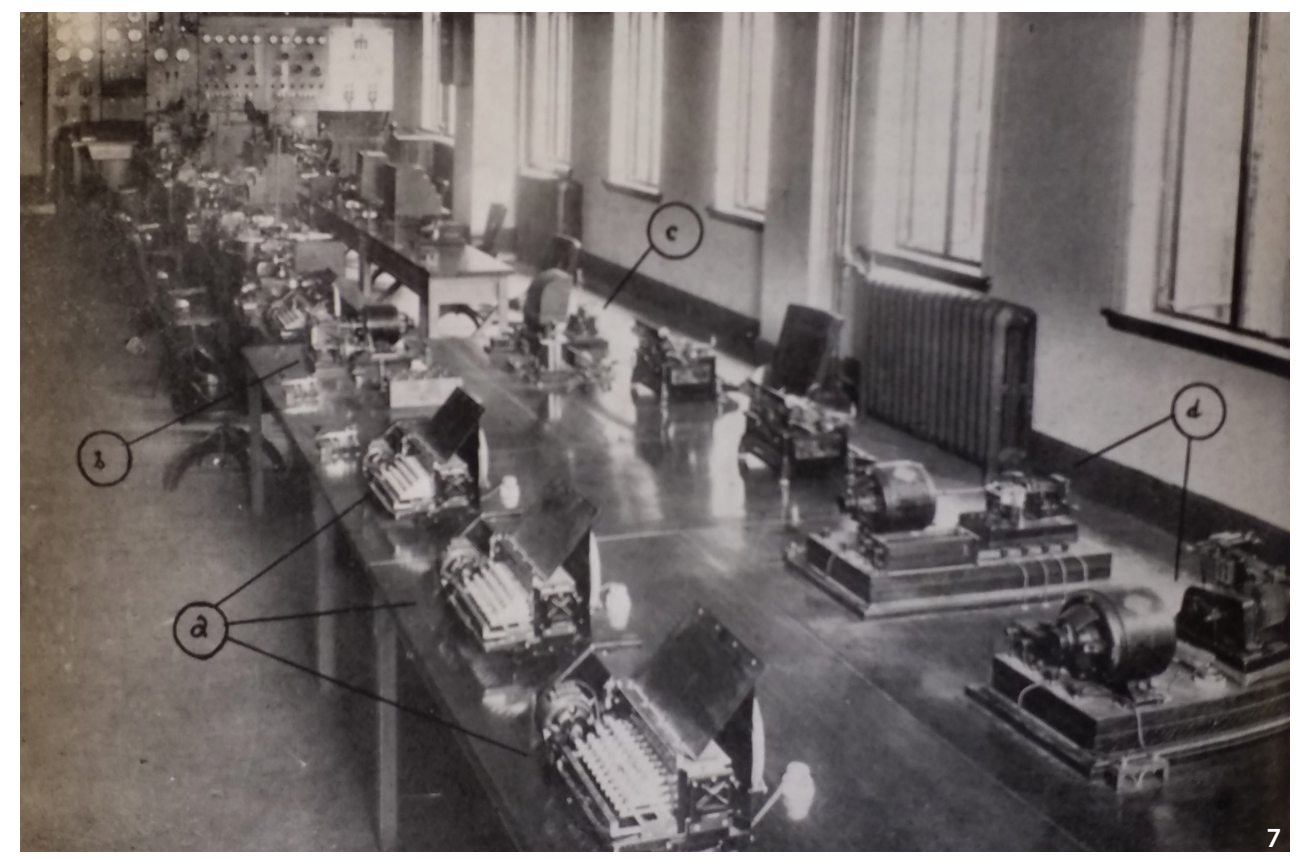

Figure 7 Sassoon House, 'Radio Central of China', Far Eastern Review (March 1931): 182.

Central Radio Office, installed in Shanghai

a. Perforating apparatus;

b. Automatic transmitter;

c. Undulator;

d. Direct printing machines.

was constitutive of modernist aesthetics (Danius 2002, 2-3) and urban heritage. Passing through their doors into sumptuously decorated interiors, the public found telegraph and telephone exchanges, and ticker tapes for real-time information on markets. The buildings were allegories to global communication. They were the nodal points that connected New York and Shanghai to the world and the mechanisms for global urban pretensions. It was precisely this euphoria about the machine age that Art Deco aesthetics attempted to capture. The 'Radio Central of China' (Figure 7) was located in Shanghai's iconic Art Deco citadel, the Sassoon House. The ground and first floors were jam-packed with transmission equipment and offices where 'messages received from all parts of the world are made ready for delivery'. It was 'in direct and permanent day and night communication with Paris' (Shecklen 1930, 290; Pavlovsky 1931, 182). This broader understanding of the heritage of modernism that embraces the technologies of movement and communication goes beyond decorative appearances to the complex fabric of structures and spaces that impacted people's lives. Heritage becomes a pathway to understanding the media revolution and future building design.

\section{Art Deco as Theatre}

Theatrical tactics and stage machinery were just as essential to modernist perception. In designing the thirty-five radio and television studios for the National Broadcasting Company at Rockefeller Center (Figure 8), architect
Raymond Hood searched for an aesthetic style in keeping with avant-garde media that were 'entirely new'. Hood was among the most celebrated architects of the age and had absorbed a riot of European influences, especially from Finish architect Eliel Saarinen as well as Walter Gropius and Adolf Meyer. Hood 'resorted to light' and 'developed an architectural effect that depended almost entirely on changing lights. Sheets of light, changing in tone and colour, stream up the wall ... Other lights glow from behind great pilasters ... The fixtures themselves, gigantic for lighting fixtures, have inside of each one an almost complete stage electrical equipment ... At the state end, a glowing screen was ingeniously devised that has almost the qualities of a colour organ. Practically, we adapted all of the tricks of stage lighting to the architecture of a room' (Hood 1928, 6). The result was Art Deco as techno-theatre for a new media that drew three-quarters of a million people to the live broadcasts in its first year of operation.

In 1926, architect and stage designer Joseph Urban designed the New York headquarters of the Hearst Publishing empire to honour his hero, the distinguished Viennese architect Otto Wagner. High-fluted columns topped with urns reproduced the imagery of the 1925 Paris Exposition, while Art Deco colossal statues at the base symbolised the publishing industry. The building exuded Urban's expertise as a theatrical stage designer. Urban was trained in Vienna and took part in the Jugendstil movement that applied modernist principles to architecture and theatre design. He was heavily 


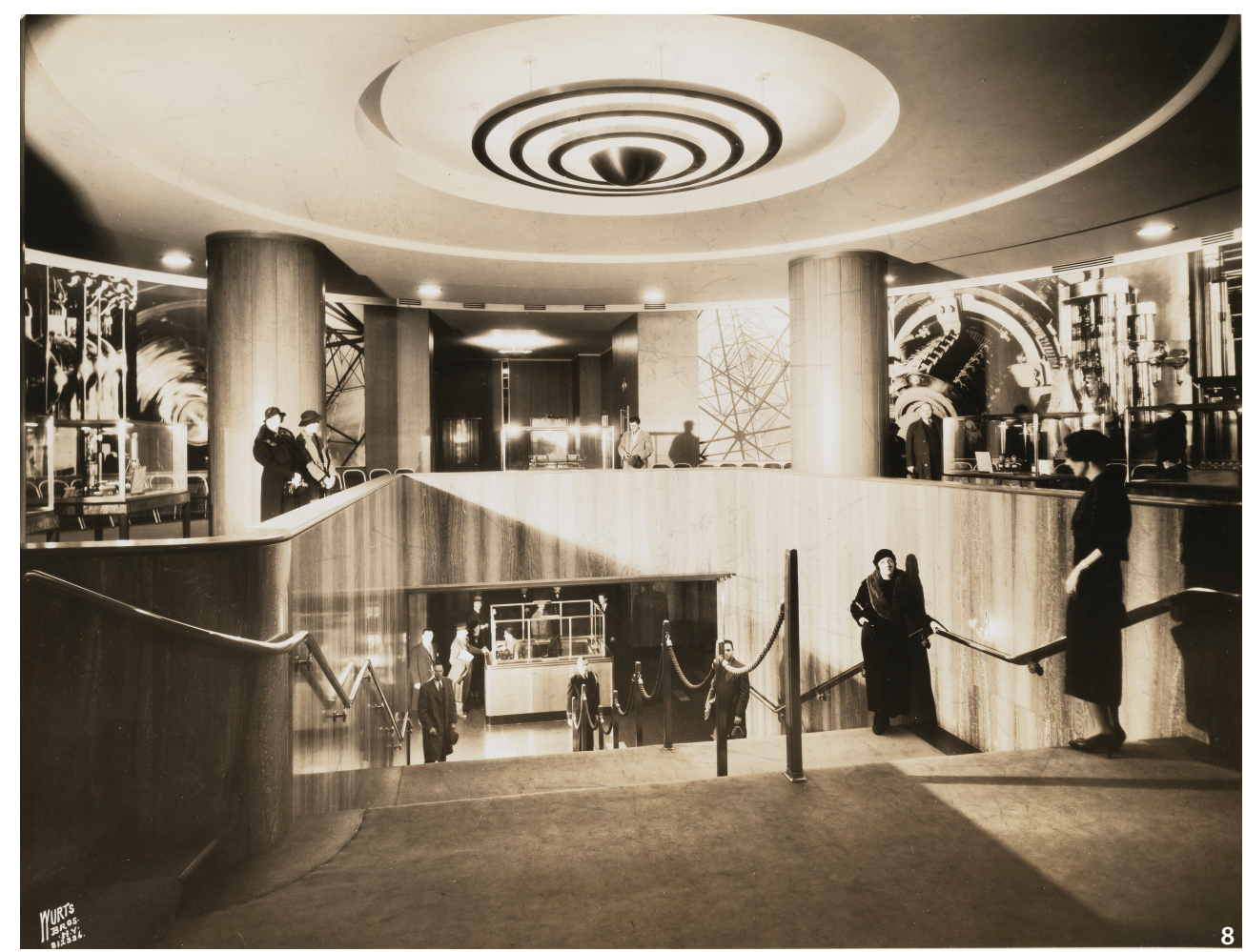

Figure 830 Rockefeller Center, Television Studio, architect Raymond Hood (Source: Museum of the City of New York). Figure 9 Joseph Urban, Ziegfeld Theater, Street Front, Watercolour, New York, 1926-1927 (Source: Joseph Urban Collection, Rare Book \& Manuscript Library, Columbia University). Figure 10 Joseph Urban, Venetian Stage Set, Ziegfeld Follies of 1921 (Source: Joseph Urban Papers, Rare Book \& Manuscript Library, Columbia University Libraries. Series III. New York).
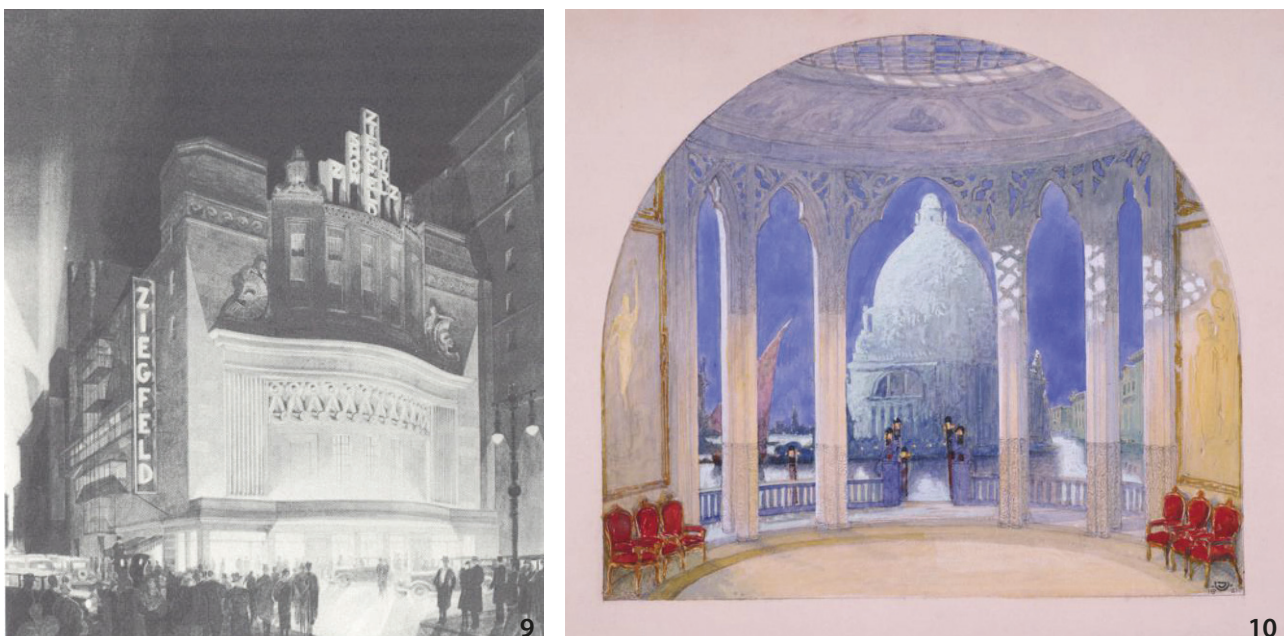

influenced by the Wiener Werkstätte. On immigrating to the United States, he opened a Wiener Werkstätte shop on Fifth Avenue to advertise their sleek crafts. In Urban's work, the theatre became an implied metaphor (Figure 9). He designed striking sets for the Ziegfeld Follies in New York, for the Metropolitan Opera and the Broadway stage. Urban argued that the inspiration for modern theatre design must come from the architect rather than the dramatist (Figure 10). Openness, elasticity of function, enveloping the audience in the production through the use of colour and lighting effects were essential to the democratic theatre (Urban 1929). Urban's buildings exuded the same drama as his theatrical stage design. They were a scenographic blend of European modernism and American commercial design. His innovative use of colour and lighting, his radical forms made his designs among the most avant-garde in New York. He employed them as well at the 1933 Century of Progress Exposition in Chicago, where he concocted an elaborate colour and lighting scheme that bathed the buildings in a 'colour geography' and unified the fairground design around the paths of sun and shade.

\section{Art Deco as Colour and Light}

In explaining his own techniques of theatrical design, American architect Claude Bragdon found parallels with architecture as a 'permanent stage set' of 'dream pictures, 

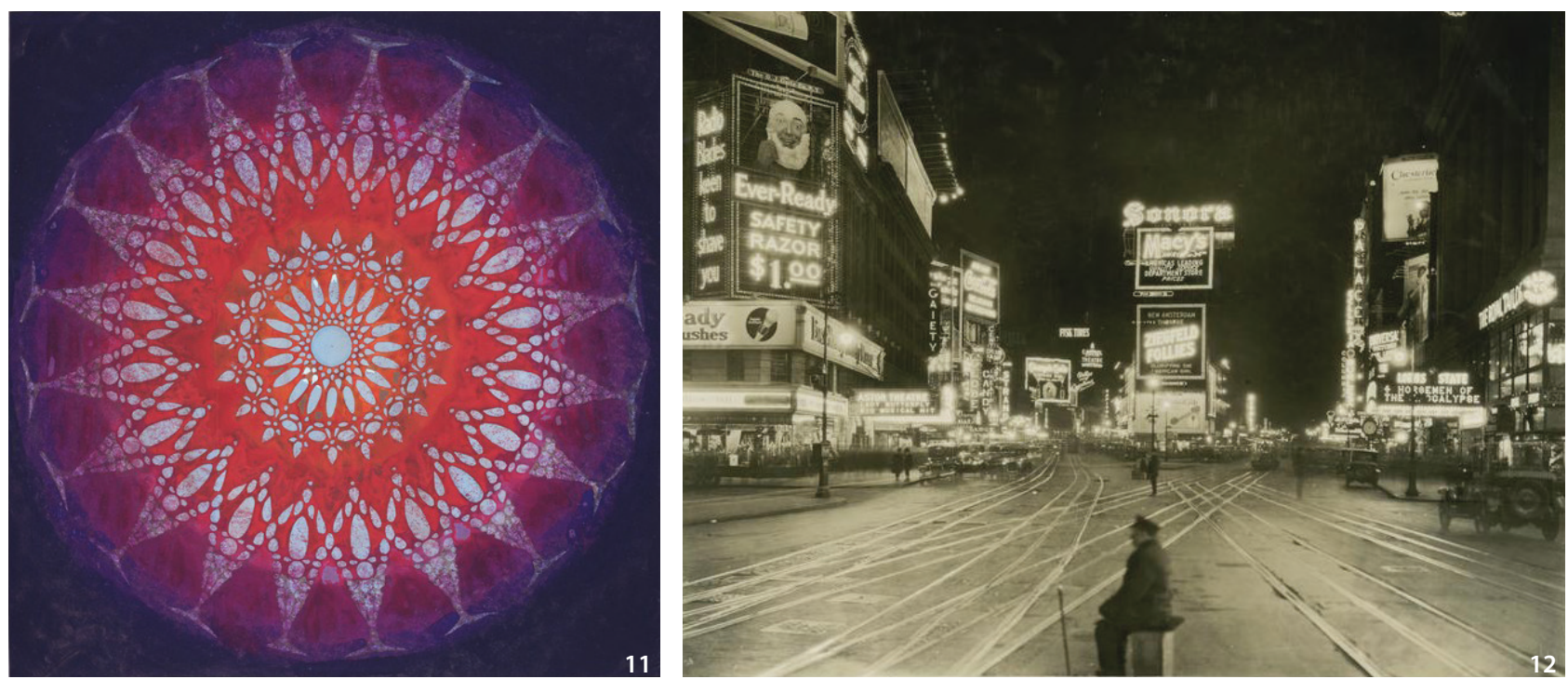

Figure 11 Claude Fayette Bragdon, Coloured Decorative Design (Source: The Miriam and Ira D. Wallach Division of Art, Prints and Photographs: Art \& Architecture Collection, The New York Public Library. 'Coloured decorative design' New York Public Library Digital Collections. Accessed June 27, 2019).

Figure 12 The Great White Way: Broadway north from $45^{\text {th }}$ Street, 1923 (Source: The Miriam and Ira D. Wallach Division of Art, Prints and Photographs: Photography Collection, The New York Public Library. 'Broadway north from 45th St.' New York Public Library Digital Collections. Accessed June 27, 2019).

as if seen in the depths of some great crystal sphere' (Figure 11). The effect was produced through colour and lighting (Bragdon 1929, 109 and 114). The taste for spectacular staging effects was derived from the emergence of modernity in the $19^{\text {th }}$ century as well as with the 'architecture of light' of European modernists. Illusions to the 'architecture of light' and to glass crystals were widely shared among avant-garde architects of this period, particularly by figures such as Walter Gropius, László Moholy-Nagy, and Bruno Taut in their writings of the 1920s and 1930s. Architect George Wilson famously designed Shanghai's Sassoon House around the Lalique glass he had admired in Paris. When the building opened in 1929, '... one almost loses interest in everything except the wonderful Lalique lighting, which is a riot of beauty ... one colour melting into another, giving the effect of sunrise and sunset, blazing day and moonlight' (North China Herald, 2 August 1929).

Most emblematic of the vintage glow of urban modernism was neon, first unveiled by French inventor Georges Claude at the Paris Motor Show in December 1910. The new methods of electrical illumination developed in the 1920s and 1930s such as neon gas-filled tubes, indirect lighting, luminous coloured lighting techniques made the built form and the spaces of New York and Shanghai into wildly aesthetic wonderlands. In Paris, officials quickly imposed legal restrictions on the use of electric advertising signage. In New York and Shanghai, neon was quickly adapted to advertising and became integral to architectural aesthetics. Focusing on lighting underscores building form as a dreamscape of colour, light, and glass. It intertwines the heritage of Art Deco with the legacy of the city as theatre. In a Shanghai review of avant-garde cinema design in Europe and the United States, the techno-drama of the Théatre Pigalle in Paris is a model in which light and machinery create magical staging. For its architect, 'the façade of a theatre is only a curtain-wall, the function of which is to serve as a background for a blazon of luminous letters .... The exterior lighting sets the dramatic atmosphere for the theatre interior conceived as 'pure architecture-the proportion of masses in voids and solids, light and shade ...' (North China Daily, 14 November 1932). These were the touchstones for aesthetic gratification and experiential authenticity. Theatrical machinery combined the sensory with architectural aesthetics.

Architectural historian Cary Y. Liu has argued that 'architecture' comprises both material and immaterial connections, as well as aesthetic concepts and standards of taste (Liu 2014, 118). Imagining built heritage as a broad phenomenon across the technological and theatrical landscape shifts our gaze to the cityscape as magical theatre in places such as the Bund, Nanjing Road, or Times Square. First introduced in Times Square, dazzling displays of moving and flashing neon lights attracted huge crowds of people (Figure 12). The content of the ads was overshadowed by the electric display. The spectacle changed the 
Figure 13 Night view of the Shanghai department stores, 1937. Claude Berruyer photographer (Source: Virtual Shanghai.net).

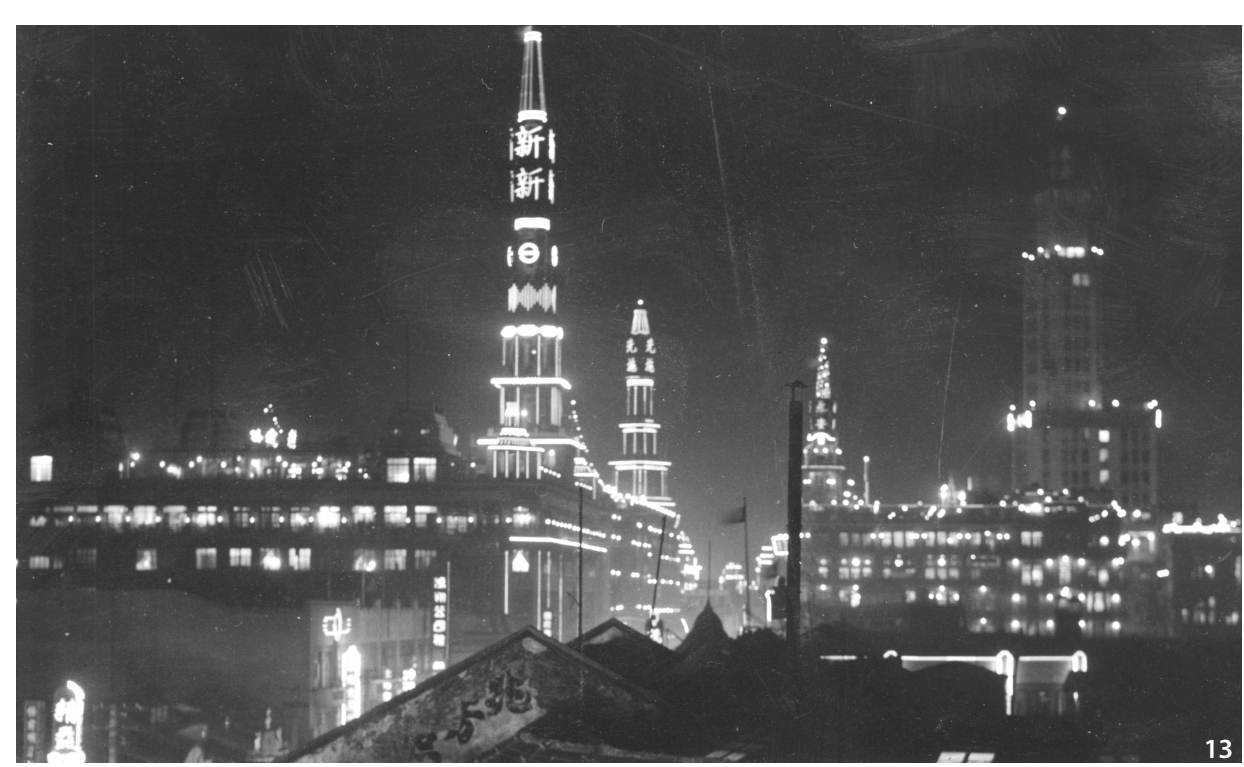

way people experienced space and made their engagement with the city a form of 'cinematic spectatorship' (Cordon $2010,65)$. The cityscape was conceived as a virtual stage set through which people moved, mesmerised by the illusionary marvels. Electric theatres such as this revealed the potential of urban space as radical avant-garde tactic. The built form of the city became sensuous display. The urban panorama was to be looked at as an image or object of aesthetic pleasure, a position increasingly reproduced in photography and film of the 1920s and 1930s. For example, the 1933 Soviet-style avant-garde montage film City Nights by director Fei $\mathrm{Mu}$, captures the carnivalesque blaze of light along the Bund, the city's signature 'poster buildings' outlined in luminous neon, the dazzling advertising displays on the Wing On, the Sincere, and Sun department stores along Nanjing Road. More than merely architectural ornament, the lavish illumination dominated cultural identity and transformed Shanghai and New York into global mass media (Figure 13). While architecture itself moved increasing toward an abstracted, minimalist modern style, the urban panorama remained ornamental, sheathed in light, ever more evocative of urban identity and experience. In good part, it was the ultimate mark of the 'society of spectacle' and demonstrated the phantasmagoria of commodification that haunted people's daily lives and, according to the urban theorists of the Frankfurt School, ultimately subjugated them.

\section{Art Deco as Commerce}

There was an intimate relationship between the avantgarde and the sorcery of commercial advertising. Glittering commercial signage became a new kind of globalised urban semiotics and a new kind of heritage. Mao Tun captured the immediacy of this visual theatre in Midnight, his seminal 1933 novel of Shanghai. Looking out over the cityscape 'one saw with a shock of wonder on the roof of a building a gigantic neon sign in flaming red and phosphorescent green: LIGHT, HEAT, POWER!' The 'kaleidoscope of red, yellow, green, black, shiny, square, cylindrical, leaping, dancing shapes' overwhelm his protagonists (Tun $2001,1,8)$. Some of the sky-signage, such as the glitzy Wrigley Spearmint Chewing Gum illumination in New York, became crowd favourites and was reproduced endlessly in photography and film as the signature of Times Square (Taylor 1991, 240-242). Others were temporary, perishable, remembered only by people who enjoyed their fleeting exoticism. In Shanghai Fox-Trot, neo-sensationalist writer Mu Shiying depicted the 'Neon light stretches out a coloured finger and writes a large character in the blackink night. An English gentleman stands in front, wearing a red swallow-tail coat, gripping a cane, vigorously striding along. Below his feet is written: "Johnny Walker: Still Going Strong"' (Mu 1934). This kind of urban spectacle was by its very nature an ephemeral art. In celebration of the 1937 coronation of King George VI, 'Shanghai burst into a joyous, display of myriad coloured lights from one end of the Bund to the other skyscraper after skyscraper blazed forth brilliantly in the night sky, making the whole waterfront a mass of twinkling light ...' (North China Herald, 19 May 1937) The riot of colour and light on the marquees in the theatre and cinema district along Broadway in New York, and the skyscrapers and cinema palaces of Shanghai made the city into illusionistic performance. 


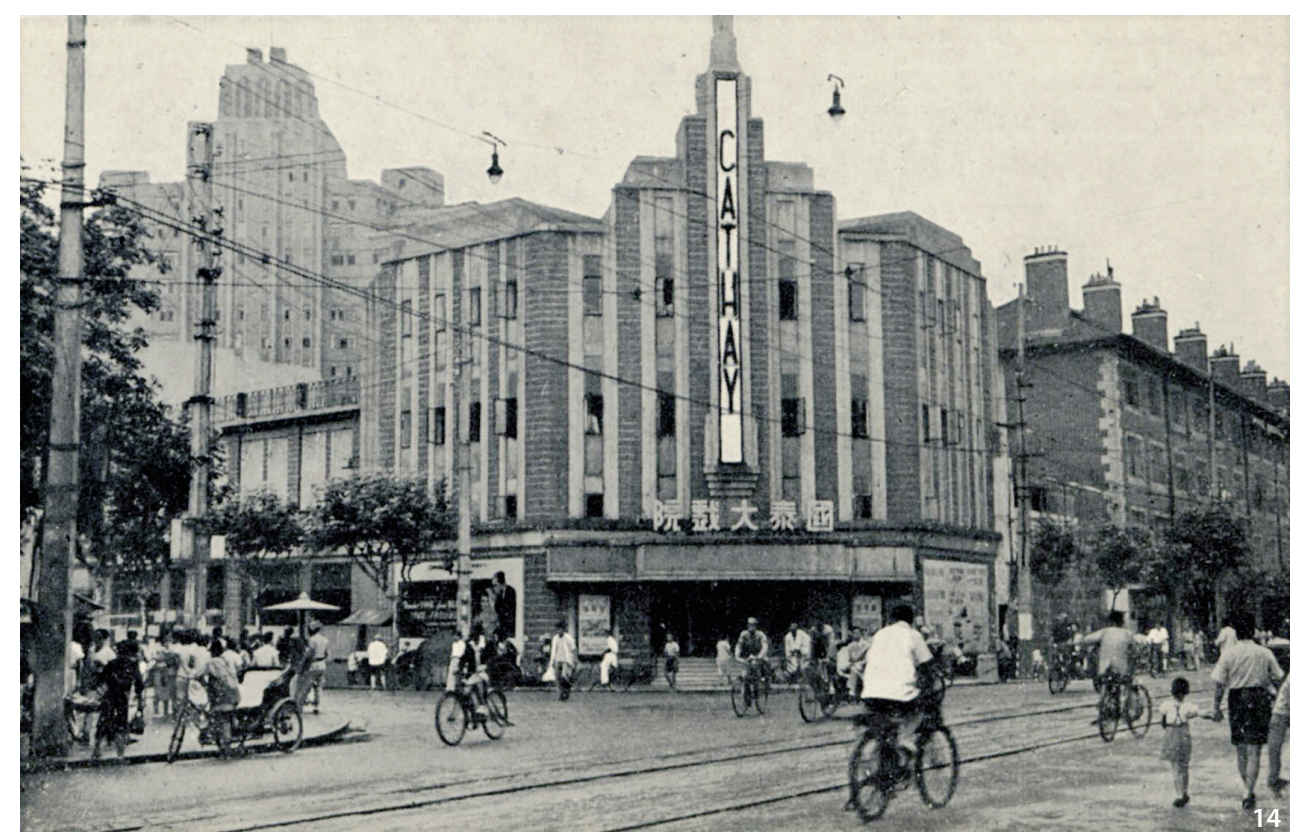

Figure 14 Cathay Theatre, 1949 (Source: Virtual Shanghai.net).

This urban spectatorship was mirrored in the Paramount Ballroom and Cathay Cinema, the Grand Theater, the cabarets and film palaces, bathed in light and decorative splendour. Along with theatre, film was also a source of inspiration, at times directly overlapping with architectural design. Joseph Urban for example designed film sets and directed numerous films for William Randolph Hearst's Cosmopolitan Productions. Cinema was the most democratic, universalist form of mass entertainment. The introduction of sound brought an entirely different quality to the illusion provided by motion pictures. Sumptuous movie theatres such as the Rialto and Roxy in New York and the Paramount and Cathay in Shanghai belonged to an era of fantasy and mirage, one that Art Deco design indulged in with abandon. The Paramount's glass tower sheathed in red and green lights could be seen for miles away (see the article by Andrew Field in this issue). The Cathay Cinema opened on January 1, 1932 with an American movie called Free Soul. Until 1949 it played English and American Films. It was designed by Czech architect Charles Henry Gonda, who also designed Shanghai's Capitol Theater and the Sun Department Store. Central Europeans added to the jumble of nationalities in Shanghai. Gonda's theatrical imagination was sharpened in Vienna and Paris where he mixed with the European avant-garde movements that were transforming architecture and design. Conda used lighting to extraordinary effect in the Cathay. The 1000-seat auditorium, done in 'American style', bathed the glass ceiling beams, the bronze and gold colour scheme in indirect lighting. The Cathay logo shot up into the sky along the building's central spire (Figure 14). The
North China Herald reported that it was 'the first time in the Far East a lighting scheme was created which architecturally constitutes a perfect unit with the decoration of the Auditorium' (5 January 1932). It was a frank assertion that a building façade was a form of advertising-a marquee. With their neon-lite spires and marble facades, the movie palaces became iconic fixtures in the city. A moviegoer effused, 'When night falls, the foreign names in neon lights on their fronts: Grand Theatre or Cathay ... glow in their alluring and glittering colours' (Poshek 2003, 34).

\section{Conclusion}

Art Deco played a significant role in the dialogue between local place and globalisation. It was a signature avant-garde production that embraced theatrics and technological wizardry and spectacularised the built environment. Both Shanghai and New York were captivated by this thrilling visualisation of the modern city. The influences that made up their urban 'styles' in the 1920s and 1930s were many. Similar avant-garde influences inspired architects in both cities. They shared inspiration from the European experiments, particularly as it was interpreted in Paris, Berlin, and more generally in central Europe. They shared in the excitement of new technologies and the brilliance of a nighttime panorama illuminated by electric stars. These facets that were so emblematic of modern urban life open a rich perspective on built heritage as do mass culture and consumption, popular entertainment and urban spectacle. Often considered ephemeral or inconsequential, these were decisive to the 
production of the urban fabric and key to what made Shanghai and New York distinctive. Not only are they an expressive fragment of the cultural legacy of the past that deserves acknowledgement. They have also inspired a discourse about both local identity and the nature of urbanity that remains to the present day. In part this narrative is nostalgic, in part it references the globalising influences and creative forces that produced the iconic New York and Shanghai 'styles'.

\section{References}

Bragdon, Claude. 1929. "The Technique of Theatrical Production." The Architectural Record 66 (2).

Cordon, Eric. 2010. The Urban Spectator: American Concept-Cities from Kodak to Google. Lebanon, NH: Dartmouth.

Danius, Sara. 2002. The Senses of Modernism: Technology, Perception, and Aesthetics. Ithaca, NY: Cornell University Press.

Delanty, Gerard. 2006. “The Cosmopolitan Imagination: Critical Cosmopolitanism and Social Theory." The British Journal of Sociology 57 (1): 25-47.

Denison, Edward. 2017. Architecture and the Landscape of Modernity in China before 1949. London \& New York: Routledge.

Gropius, Walter, and Oskar Schlemmer, eds. (1924) 2014. The Theater of the Bauhaus. Reprint, Middletown, CT: Wesleyan University Press.

Hood, Raymond. 1928. "The National Broadcasting Studios New York." The Architectural Record 64 (1).

Koolhaas, Rem. 1997. Delirious New York: A Retroactive Manifesto for Manhattan. New York: Monacelli Press.

Lee, Ou-fan Leo. "Shanghai Modern: Reflections on Urban Culture in China in the 1930s." In Alternative Modernities, edited by Gaonkar Dilip Parameshwar, 86-122. Durham and London: Duke University Press.

Liu, Cary Y. 2014. "Encountering the Dilemma of Change in the Architectural and Urban History of Shanghai." Journal of the Society of Architectural Historians 73 (1): 118-136.

Mu, Shiying. 1934. "Shanghai Fox-Trot." [Shanghai de hubuwu.] Xiandai 2 (1): 4. Translated by Andrew Field at http://shanghaisojourns.net/blog/2011/3/20/shanghai-fox-trot.html

Mumford, Lewis. 1933 “The Skyline: Skyscrapers and Tenements." The New Yorker, June 3.

Okrent, Daniel. 2003. Great Fortune: The Epic of Rockefeller Center. New York: Viking.
Paul T.Frankl. 1928. New Dimensions; the Decorative Arts of Today in Words \& Pictures. New York: Payson \& Clarke.

Pavlovsky, M., and H. Sauve. 1931. "French Equipped International Wireless Station in Shanghai." The Far Eastern Review, March.

Poncellini, Luca. 2010. Hudec László. Budapest: Holnap Kiadó.

Poshek, Fu. 2003. Between Shanghai and Hong Kong: The Politics of Chinese Cinemas. Stanford, CA: Stanford University Press.

Shecklen, George F. 1930. "Shanghai, the Radio Central of China." Far Eastern Review, June.

Sowerby, Arthur. 1928. "Shanghai's Position in the World." The China Journal 3(8).

Taylor, William R. 1991. Inventing Times Square: Commerce and Culture at the Crossroads of the World. Baltimore \& London: John Hopkins University Press.

Tschumi, Bernard. 1994. Event Cities. Cambridge, MA: MIT Press.

Tun, Mao. 2001. Midnight. Amsterdam: Fredonia Books. 